\title{
Effect of concentrations of progesterone on follicular development and fertility in beef cows
}

\author{
Jason Brian Candler \\ West Virginia University
}

Follow this and additional works at: https://researchrepository.wvu.edu/etd

\section{Recommended Citation}

Candler, Jason Brian, "Effect of concentrations of progesterone on follicular development and fertility in beef cows" (2001). Graduate Theses, Dissertations, and Problem Reports. 1285.

https://researchrepository.wvu.edu/etd/1285

This Thesis is protected by copyright and/or related rights. It has been brought to you by the The Research Repository @ WVU with permission from the rights-holder(s). You are free to use this Thesis in any way that is permitted by the copyright and related rights legislation that applies to your use. For other uses you must obtain permission from the rights-holder(s) directly, unless additional rights are indicated by a Creative Commons license in the record and/ or on the work itself. This Thesis has been accepted for inclusion in WVU Graduate Theses, Dissertations, and Problem Reports collection by an authorized administrator of The Research Repository @ WVU. For more information, please contact researchrepository@mail.wvu.edu. 


\title{
Effect of Concentrations of Progesterone on Follicular Development and Fertility in Beef Cows
}

\author{
Jason B. Candler \\ Thesis \\ Submitted to the Graduate Faculty \\ of the College of Agriculture, Forestry, and Consumer Sciences \\ at West Virginia University \\ in partial fulfillment of the requirements for the Degree of \\ Master of Science \\ in Reproductive Physiology \\ Dr. Keith Inskeep \\ Dr. Robert Dailey \\ Dr. Paul Lewis
}

Division of Animal and Veterinary Sciences

Morgantown, West Virginia

2001

Keywords: progesterone, follicle, fertility, cattle 


\section{Abstract \\ Effect of Concentrations of Progesterone on Follicular Development and Fertility in Beef Cows}

\section{Jason B. Candler}

The present study was performed to investigate the effects of low ascending concentrations of progesterone on fertility in lactating beef cattle. Cows on the low ascending progesterone treatment received $\mathrm{PGF}_{2} \alpha$ from days 3 to 4 after estrus. All cows received $\mathrm{PGF}_{2} \alpha$ on day 9 , and estradiol benzoate on day 11 . Cows were inseminated artificially 12 hours after estrus. Concentrations of progesterone were lower in treated versus control cows. Pregnancy rate did not differ between treated and control cows. Pregnancy rate was greater in cows that ovulated a follicle from the right $(78 \%)$ versus left $(52 \%)$ ovary $(\mathrm{p}<0.01)$. Low ascending progesterone early in the estrous cycle did not decrease fertility to the same extent seen with extended periods of low progesterone. 


\section{Acknowledgements}

I wish to express thanks to Drs. Robert A. Dailey and Paul E. Lewis for their guidance, constructive criticism, and encouragement. I am especially grateful to my advisor, Dr. E. Keith Inskeep for his guidance, patience, and insight into the field of reproductive physiology.

I am deeply indebted to Dr. Matt Wilson and Beth Costine for their friendships, organizational help, and participation in cattle work throughout the project. I am also grateful to Dr. Matt Wilson for his assistance with radioimmunoassays and statistical analysis. I appreciate Dr. Marlon Knights for his scientific discussions and assistance with statistical analysis. I thank Bill Ferrell for his AI technical services and jokes, and the Wardensville farm crew for their assistance and fellowship during my stay at the Reymann Memorial Farm. I thank fellow graduate students for their companionship and help.

Finally, a very special thanks goes to my family for their love, support, and understanding that have allowed me to achieve my goals. 
Table of Contents

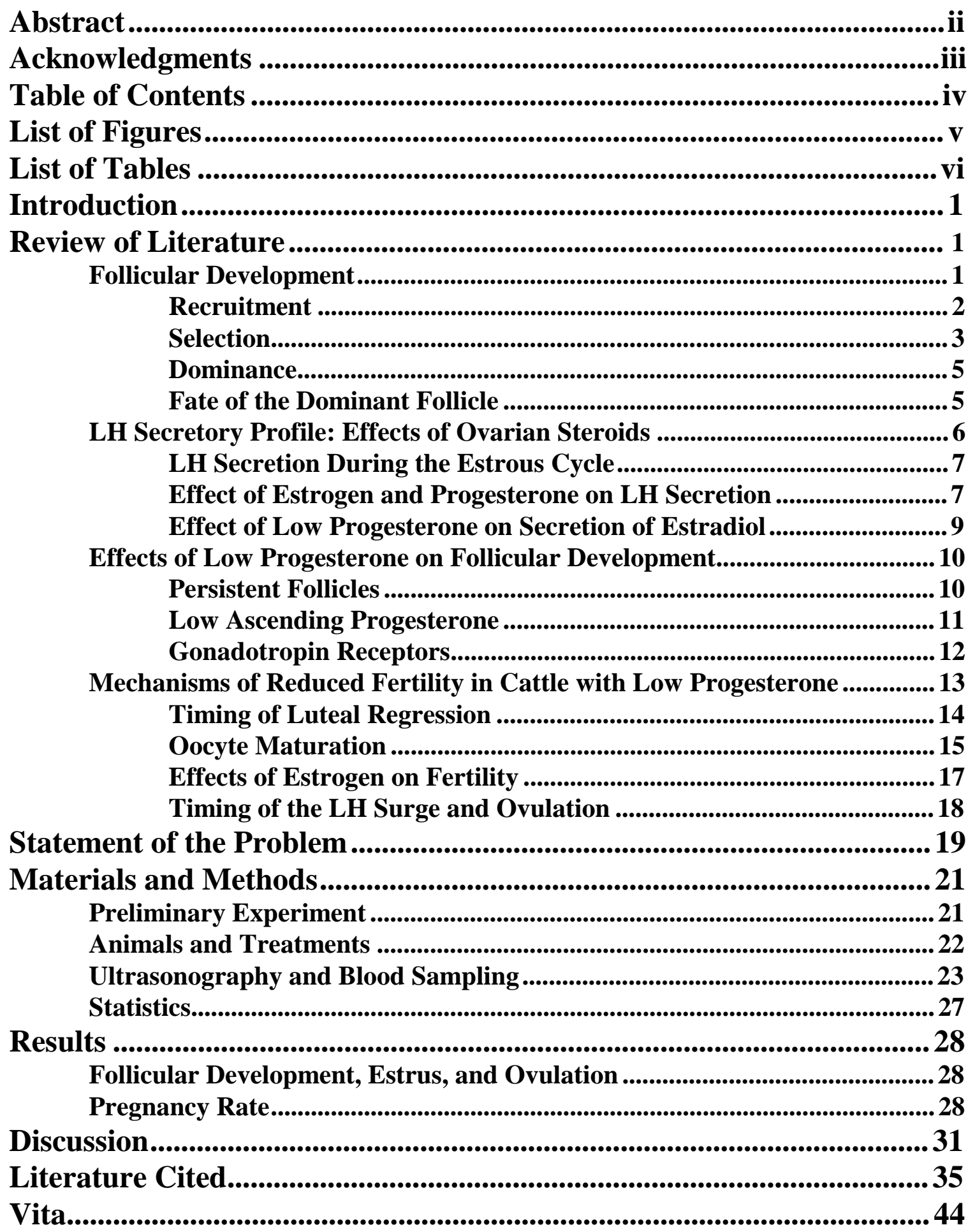




\section{List of Figures}

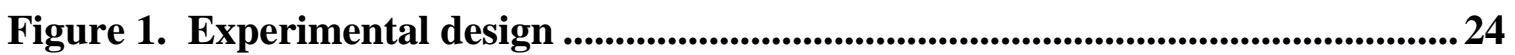

Figure 2. Concentrations of progesterone in serum of treated or control cows on days $4,6,8,9$, and 11 of the experimental estrous cycle...................................................26 


\section{List of Tables}

Table 1. Effects of treatment with $25 \mathrm{mg} \mathrm{PGF} 2 \alpha$ on days 3, 3.5, and 4 on ovulation of the first-wave follicle, estrus, days to estrus, days to ovulation, diameter of the largest follicle on day 10, and pregnancy rate in cows receiving $\mathrm{PGF}_{2} \alpha$ on day 9 of the estrous cycle.

Table 2. Effects of recorded and measured variables on pregnancy rate in cows that were in estrus and inseminated in the study. 30 


\section{Introduction}

Lowered concentrations of progesterone in cattle alter follicular development and profiles of LH and estrogen in peripheral blood. Fertility has been correlated with concentrations of progesterone during the estrous cycle before ovulation (Folman et al., 1973; Corah et al., 1974; Erb et al., 1976; Fonseca et al., 1983; Meisterling and Dailey, 1987). Low dosages of progestogens used in the synchronization of estrus can result in persistence of the dominant follicle (Sirois and Fortune, 1990; Cupp et al., 1992; Savio et al., 1993b). Fertility was low in cattle that ovulated persistent follicles (Sanchez et al., 1993; Savio et al., 1993a,b; Stock and Fortune, 1993; Wehrman et al., 1993; Mihm, 1994a; NE-161, 1996).

Follicular development, secretory profiles of LH, effects of ovarian steroids on LH, the effects of low progesterone on follicular development, and the mechanisms of reduced fertility in cattle with low progesterone will be discussed in this review. Discussion of these topics will elucidate the basis for a study of the effects of low ascending concentrations of progesterone early in the estrous cycle on fertility in beef cattle.

\section{Review of Literature}

\section{Follicular Development}

Follicular development will be reviewed in order to understand the role of the follicle in fertility. Based upon in-depth reviews (Fortune, 1994; Greenwald and Roy, 1994; Ginther et al., 1996; Ireland et al., 2000), a general scenario can be summarized. 
In mammals, a primary oocyte surrounded by a single layer of squamous granulosal cells is known as a primordial follicle. Primordial follicles remain in a resting state throughout the reproductive life of a female until unknown factors initiate their growth. Once a follicle has initiated growth, it can either continue to grow until it ovulates or undergo the degenerative process of atresia. A primordial follicle is termed a primary follicle when the granulosal cells surrounding the oocyte become cuboidal. Proliferation of granulosal cells results in a secondary follicle. A secondary follicle acquires thecal cells and forms an antral cavity to become a tertiary follicle. Granulosal and thecal cells of a tertiary follicle continue to proliferate and the antrum continues to increase in size until the follicle receives the hormonal cue to ovulate (a surge of luteinizing hormone, $\mathrm{LH}$ and follicle stimulating hormone, $\mathrm{FSH}$ ).

Follicular development occurs in two or three cohorts or "waves" during the estrous cycle of the cow (Bos taurus). Each wave begins with the growth of a cohort of several tertiary follicles. One follicle, known as the dominant follicle, will grow larger than the remainder of the follicles in the cohort. Development of follicles during each wave can be broken down into three stages: recruitment, selection, and dominance.

\section{Recruitment}

The very early stages of follicular development may occur in the absence of gonadotropins, as follicles continued to develop to early antral stages in ewes 70 days after hypophysectomy (Dufour et al., 1979). Regression or ovulation of the dominant follicle from a wave decreases the peripheral concentrations of inhibin and estrogen and allows a rise in concentration of follicle-stimulating hormone (FSH) to occur. Increased 
concentrations of FSH promote the growth of a subsequent cohort of follicles that had already reached the tertiary stage. The process by which this cohort of follicles begins growth is known as recruitment. Growth of follicles greater than $2 \mathrm{~mm}$ required gonadotropic (hCG) and somatotropic (rbST) support in ewes (Eckery et al., 1993). Treatment of pituitary stalk-transected ewes with FSH restored the number of visible follicles on the ovaries to that seen in sham-operated animals (Larson et al., 1991). FSH surges occurred 2 to 4 days before the emergence of each follicular wave was detected by ultrasound (follicle diameter 4 to $5 \mathrm{~mm}$ ) during the estrous cycle of heifers (Adams et al., 1992a). Messenger RNA (mRNA) for FSH receptor was localized to the granulosal cells of preantral primary follicles (Xu et al., 1995). These data support the integral role of FSH in follicular recruitment.

\section{Selection}

As follicles in a cohort grow, many follicles in the growing pool become atretic. This process continues until one follicle remains. The follicle that remains is termed dominant; all other follicles are termed subordinate. The process of reduction from the number of follicles that began growth during recruitment to the single dominant follicle (that usually occurs in cattle) is known as selection. The dominant follicle and the largest subordinate follicle (second largest follicle) initially grow in parallel (Ginther et al., 1996; Kulick et al., 1999). The time at which the largest subordinate follicle's growth slows, resulting in a difference in the growth rate of the two largest follicles, is known as deviation (Ginther et al., 1996). Because the slowing growth rate of the largest 
subordinate follicle is associated with the beginning of its demise, deviation has been used to mark the completion of follicular selection in cattle.

Recently, research has been focused on understanding the endocrine control of deviation. Ginther et al. (2000a) proposed that the control of deviation involved a twoway functional coupling between FSH and the follicles. As previously mentioned, a surge of FSH promotes the growth of a cohort of follicles. Growing follicles of the cohort attain the capacity to suppress FSH secretion by the time they are $5.0 \mathrm{~mm}$ in diameter (Gibbons et al., 1999), and the dominant follicle is a mean of $8.5 \mathrm{~mm}$ in diameter at the time of deviation (Ginther et al., 1996). Estrogen produced by the future dominant follicle is involved in the suppression of FSH (Ginther et al., 2000b). The declining concentration of FSH fails to support the continued growth of the subordinate follicles, but is both required and sufficient for the dominant follicle to continue to grow (Turzillo and Fortune, 1993). Primary gonadotropic support shifts from FSH to LH after the decline in FSH. Although suppression of LH did not affect the time of deviation, the diameter of the largest follicle was decreased when LH was lowered after deviation (Ginther et al., 2001). An increase in responsiveness to LH is crucial to the continued development of the dominant follicle. Granulosal cells of the dominant follicle express more LH receptor messenger RNA than those in the largest subordinate follicle before the time of deviation (Beg et al., 2001). The acquisition of LH receptors allows the dominant follicle to continue growing after the decline in FSH. 


\section{Dominance}

A follicle becomes dominant when it either suppresses the growth of all other follicles in a cohort, or continues growing in an environment that will not support the growth of subordinate follicles (Hodgen, 1982). Cauterization of the dominant follicle on day 3 after ovulation delayed the regression of the largest subordinate follicle by 6.5 days, compared to controls (Ko et al., 1991). The dominant follicle may alter the growth of other follicles by secreting a paracrine factor(s) that directly inhibits the growth of subordinates, or by altering endocrine support for subordinate follicles via negative feedback mechanisms (Fortune, 1994). The dominant follicle depends on LH for continued development. Treatment of cows with increasing doses of progesterone reduced pulse frequency of LH (but not FSH; Ireland and Roche, 1982), and treatment with dosages of progesterone that were greater than physiologic values suppressed the growth of the dominant follicle (Adams et al., 1992b).

\section{Fate of the Dominant Follicle}

After deviation, the dominant follicle continues to mature in preparation for ovulation. The most important aspect of maturation is the ability to secrete increasing amounts of estradiol, which will ultimately induce a surge of LH and subsequent ovulation (Fortune, 1994). Estradiol increases pituitary sensitivity to luteinizing hormone releasing hormone (LHRH) and release of LHRH (Kesner et al., 1981), but only if concentrations of progesterone are relatively low or have declined significantly. Progesterone inhibits gonadotropin surges (Kesner et al., 1982). Therefore, if the corpus luteum (progesterone secreting gland) does not regress, as in the case of the first and 
some second wave dominant follicles during an estrous cycle, an LH surge and ovulation

will not occur. Instead, the dominant follicle undergoes atresia, giving rise to a new wave of follicular growth.

Savio et al. (1993a) proposed that high concentrations of progesterone produced by the corpus luteum decrease LH pulse frequency and cause turnover of nonovulatory dominant follicles. Apoptosis, or programmed cell death, of follicular cells is involved in the atresia of ovarian follicles (Hughes and Gorospe, 1991; Tilly et al., 1991; Manikkam and Rajamahendran, 1997). FSH prevented spontaneous apoptosis of bovine granulosal cells in vitro (Yang and Rajamahendran, 2000). Androgens induced and estrogens inhibited apoptosis of granulosal cells in estrogen-implanted hypophysectomized immature rats (Billig et al., 1993). The direct actions of ovarian steroids on apoptosis should be investigated to improve understanding of turnover of dominant follicles in cattle.

If the corpus luteum is regressed, naturally or by treatment with prostaglandin $F_{2} \alpha$ $\left(\mathrm{PGF}_{2} \alpha\right), \mathrm{LH}$ pulse frequency will increase, causing the dominant or future dominant follicle to increase in size and to secrete more estradiol. Increasing secretion of estradiol will induce a surge of $\mathrm{LH}$ and the dominant follicle will ovulate.

\section{LH Secretory Profile: Effects of Ovarian Steroids}

Ovarian hormones (estradiol, progesterone, and inhibin) regulate the secretion of gonadotropins ( $\mathrm{LH}$ and FSH) from the anterior pituitary by positive and negative feedback mechanisms. Removal of ovarian hormones by ovariectomy results in dramatic increases in secretion of LH (Hobson and Hansel, 1972; Short et al., 1973; Beck et al., 
1976; Schallenberger and Peterson, 1982) and FSH (Schallenberger and Peterson, 1982).

Secretion of FSH is regulated by follicular estradiol and inhibin (Ginther et al., 1996).

Progesterone (Short et al., 1973; Beck et al., 1976) or estrogen (Hobson and Hansel,

1972; Beck et al., 1976) alone did not suppress an increase in LH in serum. However, treatment with progesterone and estrogen together maintained basal concentrations of $\mathrm{LH}$ in heifers (Beck et al., 1976).

\section{LH Secretion During the Estrous Cycle}

Rahe et al. (1980) measured serum LH every 10 minutes for 24 hours on day 3, 10 or 11 , and 18 or 19 of the estrous cycle of cows. On day 3, during the early luteal period, LH pulse frequency was high. On day 10 or 11, during the midluteal period, LH pulse frequency was decreased. On day 18 or 19 , the secretion of $\mathrm{LH}$ was variable. The authors speculated that the variability was due to different concentrations of ovarian steroid hormones. Ireland and Roche (1982) observed increased concentration and pulse frequency of LH (but not FSH) in cows with serum progesterone concentrations of less than $1 \mathrm{ng} / \mathrm{ml}$.

\section{Effect of Estrogen and Progesterone on LH Secretion}

The roles of both estradiol and progesterone in the inhibition of secretion of LH have been studied in the ewe. Similar results would be expected in the cow. Goodman and Karsch (1980) investigated secretion of LH in ovariectomized Suffolk ewes treated with either estradiol or progesterone. Estradiol inhibited pulse amplitude of LH, while progesterone decreased pulse frequency of LH. Gonadotropin releasing hormone $(\mathrm{GnRH})$ 
secreted by the hypothalamus causes the secretion of gonadotropins from the anterior pituitary. Estradiol (but not progesterone) inhibited amplitude of a GnRH-induced LH surge (Goodman and Karsch, 1980). Treatment of ovariectomized ewes with estradiol or progesterone decreased GnRH, measured in serial samples of hypopyseal portal blood (Karsch et al., 1987). Estradiol and progesterone decrease secretion of LH by inhibiting secretion of GnRH.

Numerous authors have investigated the effects of exogenous progestogens, administered by various delivery systems, on secretion patterns of LH in the cow (Hill et al., 1971; Ireland and Roche, 1982; Roberson et al., 1989; Kojima et al., 1992; Sanchez et al., 1995. Hill et al. (1971) found that heifers fed $0.5 \mathrm{mg}$ melengestrol acetate (MGA; an orally active progestogen) per day for 21 days had greater concentrations of LH in serum than heifers that were fed $1.0 \mathrm{mg}$ per day for the same time period. Cows given one half of a progesterone releasing intravaginal device (PRID) had greater LH pulse frequency than cows given two PRIDs (Roberson et al., 1989). LH pulse frequency increased within 6 hours after dosage of progesterone was changed from two PRIDs to one half PRID in cows. Conversely, LH pulse frequency decreased within 6 hours after dosage of progesterone was changed from one half PRID to two PRIDs (Bergfeld et al., 1996). Kojima et al. (1992) compared mean concentrations and pulse frequency of LH in cows receiving one PRID, two PRIDs, norgestomet ear implants, MGA, or no exogenous progesterone. Cows in the control group were synchronized to be in the luteal phase of their estrous cycles during the experiment. Mean concentrations of LH were lowest in control cows, and pulse frequency was highest in cows receiving norgestomet ear 
implants. These studies contributed to the idea that treatment with low concentrations of exogenous progestogens often resulted in increased LH pulse frequency.

\section{Effect of Low Progesterone on Secretion of Estradiol}

High concentrations of estradiol 17- $\beta$ have been associated with low progesterone. Bergfeld et al. (1996) found that concentrations of estradiol-17 $\beta$ increased within 6 hours after a reduction in progesterone. Both Roberson et al. (1989) and Kojima et al. (1992) found increased concentrations of estradiol-17 $\beta$ in groups of cows that had low progesterone and increased LH. Other authors who used controlled internal drug releasing devices (CIDRs) containing progesterone (Sirois and Fortune, 1990), norgestomet ear implants (Sanchez et al., 1993), and PRIDs (Wehrman et al., 1993) to induce low concentrations of progestogen, found increased serum concentrations of estradiol-17ß. Cows were given norgestomet ear implants on day 7 and either maintained the corpus luteum (CL), or were treated with $\mathrm{PGF}_{2} \alpha$ to induce regression of the CL. Cows without a CL had higher concentrations of estradiol-17 $\beta$ on day 10 (9.5 vs. 1.7 pg/ml), day 13 (12.2 vs. 1.3 pg/ml), and day 16 (11.8 vs. 2.8 pg/ml; Sanchez et al., 1993). Thecal cells produce androgens in response to $\mathrm{LH}$, while granulosal cells aromatize androgens in response to FSH (Fortune, 1994). Increased secretion of LH due to low progesterone negative feedback causes increased production of estradiol-17 $\beta$ by follicles. However, serum concentrations of estradiol- $17 \beta$ increased despite the absence of changes in the concentrations of $\mathrm{LH}$ after the removal of the $\mathrm{CL}$ in heifers anesthetized with sodium pentobarbital (Fogwell et al., 1978). 


\section{Effects of Low Progesterone on Follicular Development}

\section{Persistent Follicles}

Early investigators reported an increase in the size of the largest follicle when the amount of progesterone injected into heifers was decreased (Ulberg et al., 1951). Heifers fed MGA for 21 days had one follicle $18 \mathrm{~mm}$ in diameter and numerous other atretic follicles less than $4 \mathrm{~mm}$ in diameter (Guthrie et al., 1970). Later, studies utilizing ultrasonography confirmed that the increase in size of the largest follicle in cattle treated with low progesterone was due to a prolonged period of dominance (Sirois and Fortune, 1990; Cupp et al., 1992; Savio et al., 1993b). Numerous authors have attributed persistence of the largest follicle to increased pulse frequency of LH (Roberson et al., 1989; Sirois and Fortune, 1990; Kojima et al., 1992, 1995; Savio et al., 1993b; Sanchez et al., 1995).

Glencross (1987) stimulated the development of large follicles 1 to $2 \mathrm{~cm}$ in diameter by hourly infusion of GnRH for 5 to 11 days in luteal phase heifers either treated or not treated with a PRID. Eighty-eight percent of cows given $50 \mu \mathrm{g}$ bovine LH every 2 hours maintained the first largest ovarian follicle until day 13 (Taft et al., 1996). These studies showed that $\mathrm{LH}$, independent of a change in progesterone, can cause persistence of the dominant follicle in cattle. Thus, low progesterone allows increased LH pulse frequency, which causes continued growth and secretion of estradiol $17-\beta$ by the dominant follicle.

Increased secretion of estradiol by persistent follicles could be caused by: 1) an increase in steroidogenic enzymes involved in estrogen production, or 2) an increase in

number of steroidogenic cells (granulosal and thecal). Bigelow et al. (1998) found that 
persistent follicles had more granulosal and thecal cells than dominant follicles from control heifers, but in vitro production of estrogen by granulosal cells from persistent follicles and control follicles was not different. It was suggested that increased secretion of estradiol in persistent follicles is due to increased cell numbers. In the same study, concentrations of progesterone in follicular fluid were greatest in follicles taken 24 hours after CIDR removal from heifers induced to have persistent follicles (Bigelow et al., 1998). A fixed number of granulosal cells from these same follicles secreted the greatest amount of progesterone during a 3-hour incubation period. The authors speculated that increased pulse frequency of LH could cause premature luteinization of persistent follicles, resulting in increased progesterone production.

\section{Low Ascending Progesterone}

Shaham-Albalancy et al. (2000) gave injections of $\mathrm{PGF}_{2} \alpha$ to cows on days 3, 3.5, and 4 of the estrous cycle to cause a pattern of low ascending concentrations of progesterone. Follicles from cows with low ascending concentrations of progesterone were compared to follicles from cows with low constant concentrations of progesterone (persistent follicles) and normal concentrations of progesterone (control). The first-wave dominant follicle was atretic on day 15 in cows with low ascending and normal concentrations of progesterone, but not in cows with low constant concentrations of progesterone. The atretic first-wave follicle of cows with low ascending concentrations of progesterone was larger in diameter than the atretic first-wave follicle in cows with normal concentrations of progesterone $(15.0 \pm 1.4$ vs. $11.8 \pm 1.0 \mathrm{~mm})$. Although follicular fluid concentrations of estradiol in the first-wave atretic follicles were not different, the 
follicular fluid concentrations of estradiol in the dominant follicle were highest in cows with low constant concentrations of progesterone, intermediate in cows with low ascending concentrations of progesterone, and lowest in cows with normal concentrations of progesterone. Growth and follicular fluid concentrations of estradiol of follicles in cows with low ascending concentrations of progesterone were greater than control values, indicating that LH pulse frequency probably was increased due to lower progesterone. The first-wave dominant follicle of cows with low ascending concentrations of progesterone had characteristics intermediate to control and persistent follicles.

\section{Gonadotropin Receptors}

Another aspect of the hormonal system that should be considered in the function of persistent follicles or follicles maintained during low progesterone is receptor number. LH (but not FSH) receptor numbers were greater in granulosal and thecal cells of dominant follicles collected from cows given $6 \mathrm{mg}$ norgestomet ear implants for 9 days before the first postpartum estrus than those collected from cows that were not given ear implants (Inskeep et al., 1988). The number of LH receptors in the theca from follicles preceding the first postpartum estrus was less than in theca from follicles from cyclic cows (Braden et al., 1989). Progestogen pretreatment (endogenous or exogenous) increased numbers of LH receptors in the largest follicle. FSH and LH receptor concentrations were higher in thecal and granulosal cells from persistent follicles (Cupp et al., 1993). Therefore, continued low concentrations of progesterone could cause increased receptor numbers in persistent follicles. Altered concentrations of receptor could cause developmental changes that would ultimately affect fertility. 


\section{Mechanisms of Reduced Fertility in Cattle with Low Progesterone}

Concentrations of progesterone during the cycle prior to breeding have been correlated with fertility. Cows that conceived had higher concentrations of progesterone during the estrous cycle prior to breeding than cows that did not conceive (Folman et al., 1973; Corah et al., 1974; Erb et al., 1976; Fonseca et al., 1983; Meisterling and Dailey, 1987). Pregnancy rates (Savio et al., 1993b; Mihm et al., 1994; Smith and Stevenson, 1995; NE-161 Cooperative Research Project, 1996), oocyte viability (Revah and Butler, 1996), and embryonic survival (Ahmad et al., 1995) were decreased significantly in cows that ovulated a persistent follicle after exposure to low progesterone for seven days or more.

The mechanisms by which fertility is reduced in cows or heifers with persistent follicles due to low progesterone are not fully understood. Oocytes aspirated from persistent follicles have been found to undergo premature maturation (Revah and Butler, 1996). In a study in which fertilization rate did not differ, recovery rate of oocytes/embryos from the uterus and percentage of embryos that reached the 16-cell stage of development were decreased in cows with persistent follicles (Ahmad et al., 1995). Fertilization rate, rate of recovery from the oviduct, rate of recovery from the uterus, and development to the 4- to 8-cell stage did not differ between postpartum cows given norgestomet for 9 days or weaned controls (Breuel et al., 1993). Pregnancy rates did not differ when normal embryos were transferred to recipients that had either a persistent or control follicle (Werhman, 1997). It was suggested that fertilization rate (ovulation, oocyte transport, and sperm transport) and uterine environment are not involved in 
reducing fertility of cattle with persistent follicles. However, decreased oocyte quality, retarded embryonic development, and reduced embryonic transport may be involved.

Many studies relating fertility to progesterone profiles before ovulation have been retrospective; the effects of naturally-occurring low progesterone on fertility are not fully understood. Results from research on persistent follicles in cows with low constant exogenous progestogen can be used to speculate on mechanisms involved in decreased fertility of cattle with low progesterone prior to ovulation.

\section{Timing of Luteal Regression}

Several investigators have studied the effects of $\mathrm{PGF}_{2} \alpha$ given on different days of the estrous cycle on synchrony of estrus, interval to estrus, and fertility. Although synchrony of and time to estrus varied, pregnancy rates did not differ among heifers treated with $\mathrm{PGF}_{2} \alpha$ on days 7, 11, or 15 (Tanabe and Hann, 1984) and on days 5 to 8 or 14 to 16 (Stevenson et al., 1984) of the estrous cycle. However, Watts and Fuquay (1985) showed increasing pregnancy rates in heifers given $\mathrm{PGF}_{2} \alpha$ early, mid, or late in the estrous cycle (42.8, 62.1, and 78.3\%). Momont and Seguin (1984) reported a greater variability in the time from injection of $\mathrm{PGF}_{2} \alpha$ to estrus in Holstein heifers and cows treated on day 10 compared to those treated on day 7 or 8 . Pregnancy rate was greater in heifers given $\mathrm{PGF}_{2} \alpha$ on day 7 (73\%) than in heifers given $\mathrm{PGF}_{2} \alpha$ on day $10(21 \%)$. Cows treated on day 10 may have ovulated a follicle from the first or second follicular wave while cows treated on day 7 or 8 probably ovulated follicles from the first follicular wave. Therefore, differences in synchrony of estrus and pregnancy rate are most likely due to 
the time of treatment with $\mathrm{PGF}_{2} \alpha$ in relation to stage of the follicular wave (and whether a persistent or a growing follicle ovulated), not day of the estrous cycle.

\section{Oocyte Maturation}

Oocyte maturation and the factors that regulate this process in cattle have been reviewed in depth (Bevers et al., 1997; Taft, 1999). Oocytes are arrested in prophase of the first meiotic division until just before ovulation in ruminants. The LH surge is the normal preovulatory trigger that initiates resumption of meiosis by the oocyte (Bevers et al., 1997). An infusion of LH insufficient to cause ovulation stimulated oocytes in rats and rabbits to undergo premature maturation (Mattheij, 1994). Bovine oocytes aspirated from persistent follicles were shown to have resumed meiosis prematurely (Revah and Butler, 1996). The authors speculated that increased LH pulse frequency in cows with persistent follicles may be sufficient to induce oocyte maturation. More oocytes from heifers treated with a norgestomet ear implant for ten days had resumed meiosis than oocytes from heifers treated for two days (Mihm et al., 1999). The authors proposed that oocytes from follicles with a duration of dominance greater than ten days resumed meiosis. However, Taft (1999) observed changes in the oocyte associated with the resumption of meiosis after only two days of low progesterone.

During the development of a follicle, cumulus cells form processes that extend through the zona pellucida and form gap junctions with the oolemma (Zamboni et al., 1972). These processes allow communication between the oocyte and cumulus cells. Both stimulatory and inhibitory compounds affecting resumption of meiosis in the oocyte have been identified. Pincus and Enzman (1935) first proposed that the cumulus cells 
supply a substance(s) to the ovum that directly inhibits nuclear maturation. Disruption of cumulus-oocyte communication causes the oocyte to resume meiosis (Dekel and Beers, 1978). Stimulation of cumulus-oocyte complexes with LH decreased the number of gap junctions, and the transport of inhibitory compounds to the oocyte, allowing meiosis to proceed (Dekel and Beers, 1978; Granot and Dekel, 1994, 1998). Therefore, increased LH pulse frequency may cause the retraction of cumulus processes, which in turn allows the oocyte to resume meiosis.

Embryo viability could be compromised by advancement of oocyte maturation. The oocyte and early embryo depend on maternal mRNA to function before the embryo can transcribe its own mRNA. More than 300 peptides are translated from the maternal mRNA in the early murine embryo (Menezo and Renard, 1993). The bovine embryo begins transcribing embryonic mRNA when it reaches the 8- to 16-cell stage (Telford et al., 1990). The development of bovine embryos beyond the 8-cell stage was decreased in cows that ovulated persistent follicles (Ahmad et al., 1995). Premature maturation of an oocyte could deplete or alter maternal mRNA necessary for early development of an embryo, resulting in decreased embryonic survival.

\section{Effects of Estrogen on Fertility}

Research in other species supports the role of estradiol in reduced fertility in animals with low progesterone. When ovulation was delayed by as little as 48 hours in rats, concentrations of estradiol increased in follicular fluid, implantation rate was decreased and embryonic death was increased. When rats were treated with antiserum 
against estrogen, the detrimental effects of estrogen were ablated (Butcher and Pope, 1979). However, changes in the oocyte associated with decreased fertility occurred in cows with persistent follicles in which follicular fluid and serum concentrations of estradiol were reduced to trace amounts (Revah and Butler, 1996). In their 1996 review, Bevers et al. (1997) concluded that steroids played no role in the resumption of meiosis in cattle.

Although estradiol may not affect oocyte maturation, it could affect embryonic transport and reduce fertility. It has long been known that the ratio of estrogen to progesterone affects the motility of the reproductive tract. Treatment of ovariectomized ewes with estradiol benzoate caused fluid in the oviduct to flow away from the uterus (McDonald and Bellve, 1969). Booth et al. (1975) found that the recovery rate of embryos was decreased in heifers that had high peripheral concentrations of estradiol. Cows with normally developing embryos had higher concentrations of progesterone and lower estradiol to progesterone ratios on days 3 and 6 (Maurer and Echternkamp, 1982). In the same study, cows in which no embryos were recovered had an increased interval from the onset of estrus to the LH surge. Increased secretion of estrogen due to prolonged low concentrations of progesterone could decrease fertility by altering embryonic transport to the uterus.

\section{Timing of the LH Surge and Ovulation}

Low concentrations of progesterone could alter the timing of the LH surge and ovulation in relation to estrus and affect fertility. Treatment of ewes with vaginal sponges containing flurogestone acetate altered the timing of the $\mathrm{LH}$ surge in relation to estrus. 
The LH surge occurred later in relation to the onset of estrus in ewes treated with $40 \mathrm{mg}$ flurogestone acetate than in ewes treated with $20 \mathrm{mg}$ flurogestone acetate and fertility was greater in the ewes receiving the higher dosage (Lewis et al., 1974). The interval from the end of estrus to ovulation was 4.1 hours longer in heifers synchronized with dihydroxyprogesterone acetophenide than in control heifers, and pregnancy rate was lower in synchronized heifers $(32 \%)$ than in control heifers (50\%; Wiltbank et al., 1967). 


\section{Statement of the Problem}

Reproduction is the most important requisite of beef cattle production. Without the birth of a live calf, there is no potential for profit. Cows that do not become pregnant to the first breeding yield less potential profit. Repeat breeders require additional breeding (artificial insemination) and management expenses, and wean a younger, lighterweight calf. Methods to improve reproductive performance of beef cattle are of great interest to beef cattle producers.

Use of exogenous hormones to synchronize estrus is one method for management of reproduction in beef cattle. This procedure, if successful, shortens the breeding and calving seasons. Estrous synchronization allows producers to improve genetics of their herds by artificially inseminating with semen from genetically superior bulls. The use of low dosages of exogenous progestogens for extended periods of time in synchronization regimens results in a large percentage of animals in estrus; however, fertility at this estrus has been lower than fertility at a spontaneous estrus. Lower concentrations of progesterone during the cycle before ovulation have been correlated directly with decreased fertility.

The mechanisms by which fertility is reduced in cattle with low concentrations of progesterone are not fully understood. Low, constant progesterone results in an increase in LH pulse frequency. The LH surge initiates the resumption of meiosis in the oocyte. Increased LH pulse frequency might initiate oocyte maturation too early in relation to fertilization, resulting in an embryo that is not viable. Increased secretion of estradiol could reduce fertility by inhibiting embryonic transport. 
Fertility was decreased in cows with lower concentrations of progesterone during the cycle before ovulation (Folman et al., 1973; Corah et al., 1974; Erb et al., 1976; Fonseca et al., 1983; Meisterling and Dailey, 1987). A recent study (Shaham-Albalancy et al., 2000) has shown that a pattern of low ascending progesterone affects development of the follicle, but to a lesser degree than low constant progesterone. The present study was performed to investigate the effects of low ascending concentrations of progesterone on fertility of the first service in beef cows ovulating the first wave dominant follicle. 


\section{Materials and Methods}

\section{Preliminary Experiment}

Ovulation of the first wave dominant follicle on the same day of the estrous cycle would allow comparison of fertility in cows with different profiles of progesterone, but with the same follicular age. Treatment regimens that would allow ovulation of the first wave dominant follicle in lactating beef cows with normal or low ascending profiles of progesterone were required for this study. Injections of $25 \mathrm{mg} \mathrm{PGF}_{2} \alpha$ given to Holstein heifers twice daily on day 4 or days 2 and 3 inhibited progesterone secretion but did not alter estrous cycle length (Beal et al., 1980). Shaham-Albalancy et al. (2000) gave dairy cows injections of $25 \mathrm{mg} \mathrm{PGF}_{2} \alpha$ on days $3,3.5$, and 4 of the estrous cycle to induce a low ascending profile of progesterone. The day of the estrous cycle to give an injection of $\mathrm{PGF}_{2} \alpha$ to cause regression of the corpus luteum and ovulation of the first wave dominant follicle was selected based on the following literature.

Emergence of the second follicular wave occurred on day 10 in heifers with 2wave estrous cycles and day 9 in cows with 3-wave estrous cycles (Ginther et al., 1989). Momont and Seguin (1984) reported greater variability in the interval from injection of $25 \mathrm{mg} \mathrm{PGF} 2 \alpha$ to estrus in heifers treated on day 10 than in heifers treated on days 7 and 8. It was reasoned that heifers treated with $25 \mathrm{mg} \mathrm{PGF} 2 \alpha$ on day 7 or 8 most likely ovulated a first wave follicle, while heifers treated on day 10 may have ovulated a first or second wave follicle. Because a second wave follicle would produce less estrogen than a first wave follicle on day 10 of the estrous cycle, heifers that ovulated a second wave follicle would show estrus later than heifers that ovulated a first wave follicle. Day 9 was selected to maximize the time from low progesterone to ovulation of a first wave 
dominant follicle in treated animals, but avoid ovulation of a second wave follicle.

A preliminary experiment was performed to determine if cows injected with 25 mg $\mathrm{PGF}_{2} \alpha$ on days $3,3.5$, and 4 of the estrous cycle and cows not treated with $\mathrm{PGF}_{2} \alpha$ would ovulate the first wave dominant follicle after an injection of $25 \mathrm{mg} \mathrm{PGF}_{2} \alpha$ on day 9. Cows $(n=15)$ located at the WVU Reedsville Farm were observed a minimum of 30 minutes twice daily for signs of estrus. Cows $(n=8)$ received three $25 \mathrm{mg}$ injections of $\mathrm{PGF}_{2} \alpha$ (i.m.) on days 3, 3.5, and 4 after estrus. All cows were injected with $25 \mathrm{mg} \mathrm{PGF}_{2}$ $\alpha$ (i.m.) on day 9 after estrus, and ovaries of all cows were examined daily using transrectal ultrasonography (Aloka Model \#SSD-500) equipped with a 7.5 MHZ lineararray transducer. Time of ovulation was identified as the first examination at which the largest follicle was no longer detected.

All cows were in estrus within four days after injection with $25 \mathrm{mg} \mathrm{PGF}_{2} \alpha$ on day 9. Ovulation of the first wave dominant follicle was detected within five days after injection with $25 \mathrm{mg} \mathrm{PGF} 2 \alpha$ on day 9 in all except one control cow. The dominant follicle appeared to luteinize in the cow in which ovulation was not detected. Therefore, day 9 was considered to be a suitable time for initiation of luteal regression in the main experiment.

\section{Animals and Treatments}

During the summer of 2000, 112 lactating beef cows on two farms were used for this experiment. All cows were observed a minimum of 30 minutes twice daily for signs of estrus. Cows $(n=72)$ at the WVU Reymann Memorial Farm were moved from pasture to drylot within four days after detection of estrus for easier handling. Cows were 
fed hay free choice and a maintenance grain supplement while in the drylot. After completion of treatments, cows were returned to pasture. Body condition scores from 47 cows evaluated in this herd averaged 6.6 and ranged from 6 to 8 . Cows $(n=40)$ at the WVU Reedsville Farm were maintained on pasture for the duration of the experiment. Body condition scores from all cows in this herd averaged 6.5 and ranged from 5 to 9 in this herd.

After detection of estrus, cows were assigned at random to one of two treatment groups (Figure 1). Cows on the low ascending progesterone treatment received three injections of $25 \mathrm{mg} \mathrm{PGF} 2 \alpha$ (i.m.) on days 3, 3.5, and 4 after estrus (Shaham-Albalancy, 2000). All cows were injected with $25 \mathrm{mg} \mathrm{PGF}_{2} \alpha$ (i.m.) on day 9 , and with $400 \mu \mathrm{g}$ estradiol benzoate (i.m.) on day 11 to synchronize estrus. Cows detected in estrus after the injections of $\mathrm{PGF}_{2} \alpha$ and estradiol benzoate were artificially inseminated 12 hours later. Two experienced technicians inseminated cows, one at each location. Semen from a single bull of high fertility was used to inseminate cows at the Reedsville farm, while semen from four bulls of high fertility was used to inseminate cows at the Reymann Memorial Farm.

\section{Ultrasonography and Blood Sampling}

Ovaries of all cows were examined using transrectal ultrasonography (Aloka Model \#SSD-500) equipped with a 7.5 MHZ linear-array transducer on days 4, 6, 8, 10, and daily until ovulation occurred. Significant ovarian structures (follicles $>6 \mathrm{~mm}$ and corpora lutea) were recorded on ovarian maps. Time of ovulation was identified as the 


\section{Control}

$400 \mu \mathrm{g}$ Estradiol Benzoate

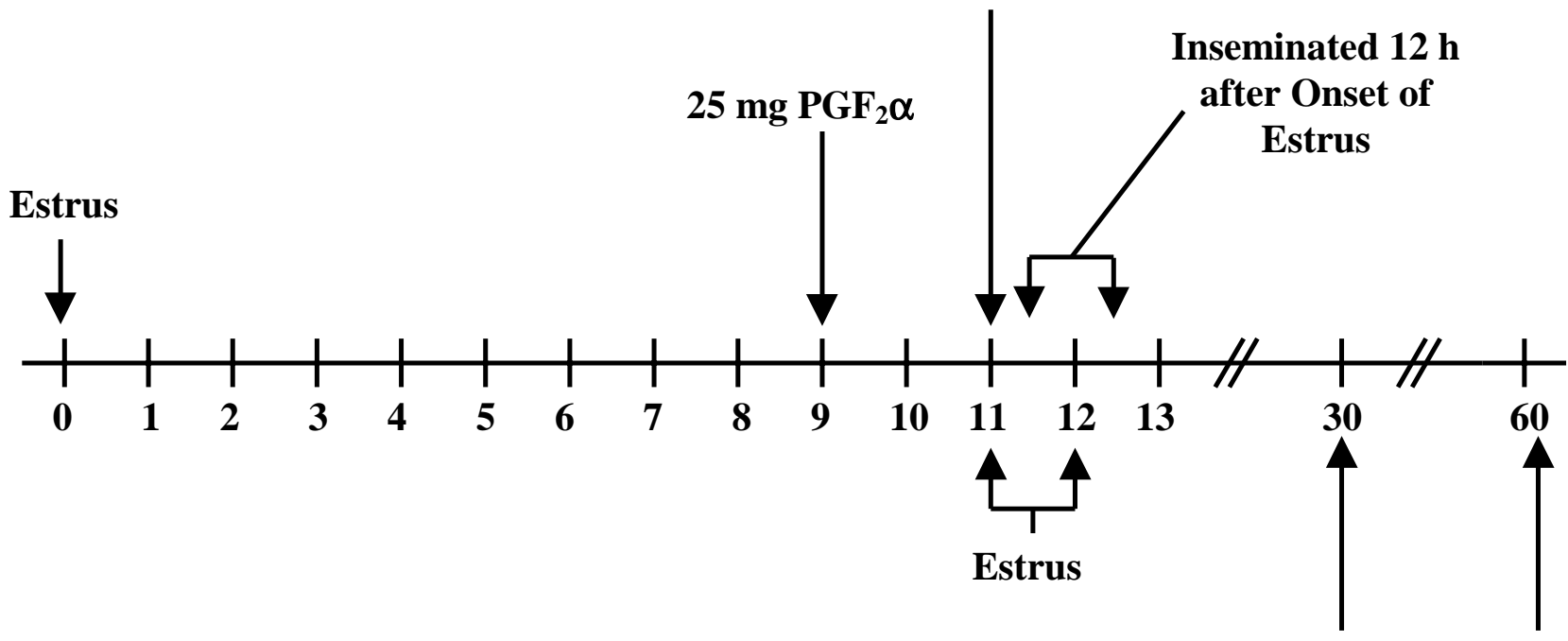

Treated

$400 \mu \mathrm{g}$ Estradiol Benzoate

Ultrasound for

Pregnancy

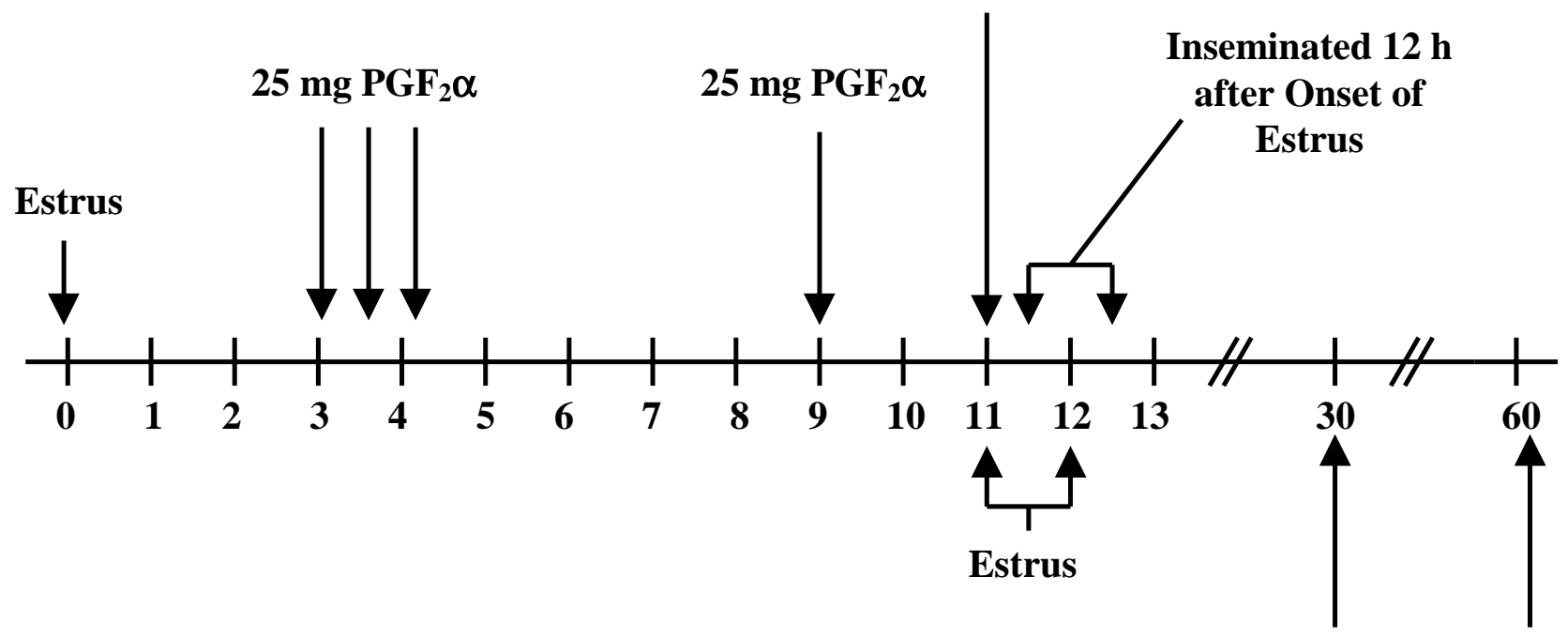

Ultrasound for Pregnancy

Figure 1. Experimental Design. In addition to treatments and observations shown, ovaries of all cows were examined using transrectal ultrasonography on days 4, 6, 8, 10 and daily until ovulation occurred; and jugular venous blood samples were taken on days $4,6,8,9$, and 11 . 
first examination at which the largest follicle was no longer detected. Jugular venous blood samples were taken on days $4,6,8,9$, and 11 and stored overnight at $-20^{\circ} \mathrm{C}$. Serum was separated by centrifugation and stored at $-20^{\circ} \mathrm{C}$ until assayed for progesterone.

Serum samples were assayed for progesterone as described by Sheffel et al. (1982). All samples from a cow were measured in duplicate in the same assay. To verify that treatment altered the progesterone profile, values for progesterone were examined by ANOVA for a split plot with farm, treatment, cow within farm by treatment, day, and day by treatment interaction included in the model. Values for concentration of progesterone from 81 cows that completed the experiment (i.e., were detected in estrus, artificially inseminated, and ovulated the first-wave dominant follicle) were included in this analysis. The curve of progesterone was reduced in treated versus control cows (Figure 2). Average concentrations of progesterone on days 4, 6, and 8 were lower in cows at the Wardensville farm $(3.1 \pm 0.2 \mathrm{ng} / \mathrm{ml})$ than in cows at the Reedsville farm $(4.0 \pm 0.2$ $\mathrm{ng} / \mathrm{ml})$.

All cows that completed the experiment and did not return to estrus were examined for pregnancy by transrectal ultrasonography at approximately days 30 and 60 after artificial insemination. Pregnancy was determined by the visualization of an embryonic/fetal heartbeat. If no heartbeat was detected, cows were reexamined the following week. A cow was categorized as non-pregnant if no signs of pregnancy were detected. Calving records from the spring of 2001 were used to ensure accuracy of ultrasound data. Five cows that were categorized as non-pregnant at day 30 and pregnant 


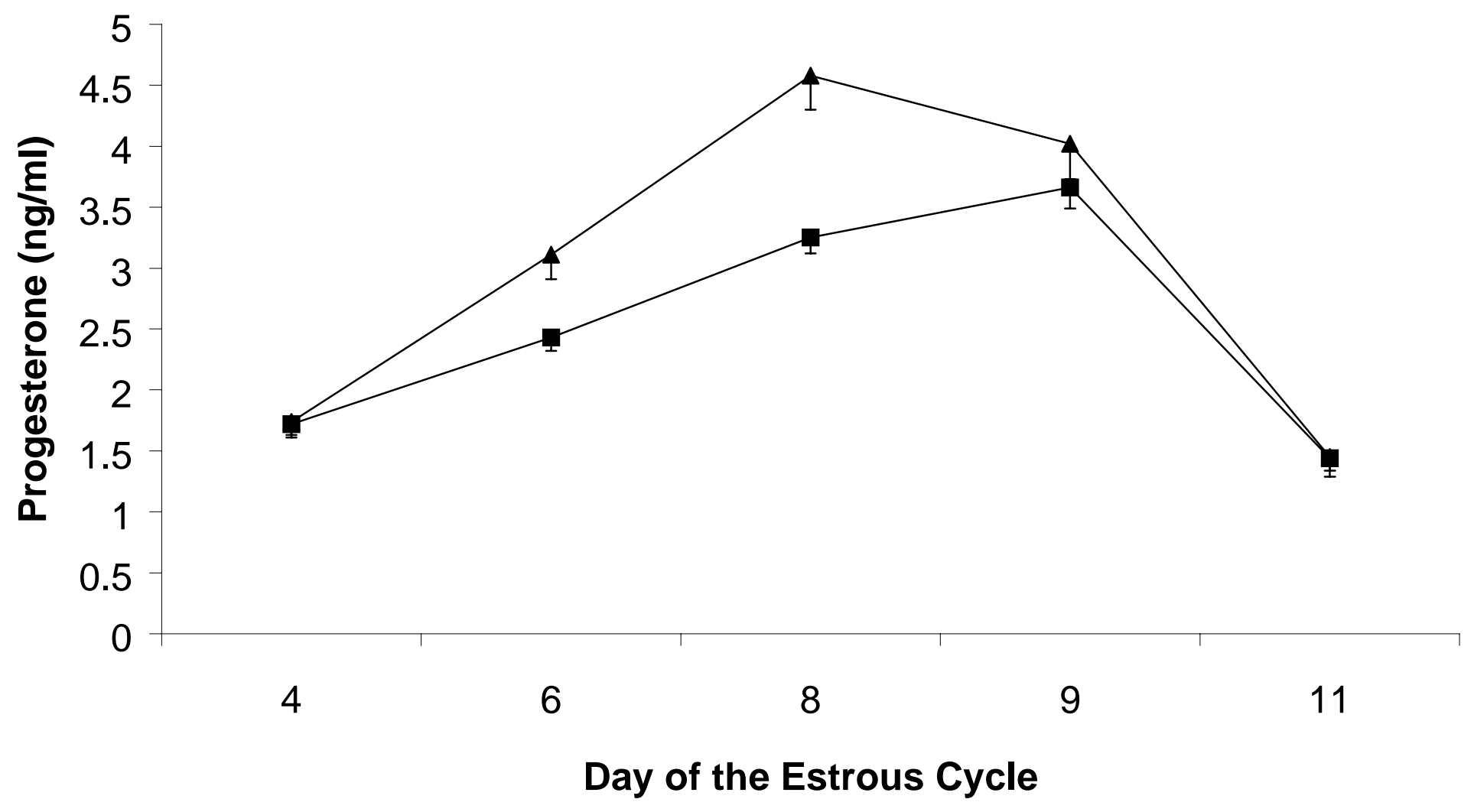

Figure 2. Mean concentrations of progesterone in serum of treated (squares; $n=41$ ) or control (triangles; $\mathrm{n}=40$ ) cows on days $4,6,8,9$, and 11 of the experimental estrous cycle. 
at day 60 calved at the expected calving date corresponding to the artificial insemination. These cows were included in the analysis of pregnancy rate as pregnant.

\section{Statistics}

Data from 112 cows were available for analysis of occurrence of estrus, ovulation of the first-wave follicle, and diameter of the largest follicle on day 10. Twenty-five cows were not detected in estrus and were not included in the analysis of days to estrus after injection of $\mathrm{PGF}_{2} \alpha$. Ovulation was not detected in 26 cows. Data from these cows were not included in the analysis of days to ovulation after injection of $\mathrm{PGF}_{2} \alpha$. Body condition scores of the 66 cows evaluated were distributed as follows: $5(n=1), 6(n=36), 7(n=$ 24), $8(n=4), 9(n=1)$. A total of 81 cows completed the experiment and were included in the analysis of pregnancy rate.

Effects of treatment, farm, and treatment by farm interaction on diameter of the largest follicle on day 10 of the estrous cycle were examined by ANOVA using the GLM procedure of SAS. The remaining tests were examined using the CATMOD procedure of SAS. Treatment, farm, and treatment by farm interaction were included in the model for estrus, ovulation of the first-wave follicle, days to estrus after injection of $\mathrm{PGF}_{2} \alpha$ on day 9, days to ovulation after injection of $\mathrm{PGF}_{2} \alpha$ on day 9, and diameter of the largest follicle on day 10. Treatment, farm, body condition score at the beginning of the experiment, and service sire were included in the model for pregnancy rate. Variables included in the second model used to analyze pregnancy rate were days to estrus after injection of $\mathrm{PGF}_{2} \alpha$ on day 9 , rank of the average concentration of progesterone on days 4,6 , and 8 within treatment, rank of the slope of the concentrations of progesterone on days 4,6 , and 8 
within treatment, and side of ovulation. Effects of insemination technician were confounded with farm, thus technician was not considered separately.

\section{Results}

\section{Follicular Development, Estrus, and Ovulation}

There was no effect of treatment on the diameter of the first-wave dominant follicle on day 10 (Table 1). Diameter of the first-wave dominant follicle on day 10 was significantly larger in cows at the Reedsville farm $(14.5 \pm 0.2 \mathrm{~mm})$ than in cows in the herd at Wardensville $(13.2 \pm 0.2 \mathrm{~mm} ; \mathrm{p}<0.01)$. Neither the proportion of cows that were detected in estrus (78\%) nor the proportion that ovulated the first-wave dominant follicle (77\%) was affected by treatment (Table 1) or farm. There was no effect of farm or treatment on the intervals from injection of $25 \mathrm{mg} \mathrm{PGF}_{2} \alpha$ on $\mathrm{d} 9$ to estrus or ovulation. None of these variables were affected by an interaction of farm or treatment.

\section{Pregnancy Rate}

Pregnancy rate did not differ between treated (68\%) and control (70\%) cows or between cows housed at the Reedsville (76\%) and Wardensville (65\%) farms (Table 1). Pregnancy rate was greater $(\mathrm{p}<0.01)$ in cows that ovulated a follicle from the right $(78 \pm$ $6 \%)$ versus left (52 $\pm 10 \%)$ ovary. Body condition score, service sire, diameter of the largest follicle on day 10, days from injection of $\mathrm{PGF}_{2} \alpha$ to estrus, rank of the average concentration of progesterone from days 4 through 8 within treatment, rank of the slope of the concentrations of progesterone on days 4,6 , and 8 within treatment, and side of previous corpus luteum did not affect pregnancy rate (Table 2). 
Table 1. Effects of treatment with $25 \mathrm{mg} \mathrm{PGF}_{2} \alpha$ on days 3, 3.5, and 4 on ovulation of the first-wave follicle, estrus, days to estrus, days to ovulation, diameter of the largest follicle on day 10 , and pregnancy rate in cows receiving $\mathrm{PGF}_{2} \alpha$ on day 9 of the estrous cycle.

\begin{tabular}{lll} 
Variable & Treated & Control \\
\hline $\begin{array}{l}\text { Diameter of the Largest } \\
\text { Follicle on Day 10 }\end{array}$ & $13.7 \pm 0.2 \mathrm{~mm}$ & $13.6 \pm 0.2 \mathrm{~mm}$ \\
Estrus & $45 / 57(79 \%)$ & $42 / 55(76 \%)$ \\
Days to Estrus & $2.5 \pm 0.1$ days & $2.6 \pm 0.1$ days \\
$\begin{array}{l}\text { Ovulation of the } \\
\text { First-Wave Follicle }\end{array}$ & $13.6 \pm 0.2 \mathrm{~mm}$ \\
$\begin{array}{l}\text { Days to Ovulation } \\
\text { Pregnancy Rate for Cows } \\
\text { in Estrus and Ovulated }\end{array}$ & $3.9 \pm 0.1$ days & $4.0 \pm 0.1$ days \\
& & $28 / 41(68 \%)$
\end{tabular}

$\overline{\mathrm{a}}$ Thirty one cows that were not detected in estrus and/or were not detected to ovulate the first wave follicle were not included in the analysis of pregnancy rate 
Table 2. Effects of recorded and measured variables on pregnancy rate in cows that were in estrus and inseminated in the study.

Variable

Body Condition Score

$5-6$

$7-9$

Service Sire

123

535

539

61195

Diameter of the Largest

Follicle on Day 10

$<12$

12

13

14

15

16

- 17 n

27/36

$14 / 24$
Pregnancy Rate

$75 \%$

$58 \%$

$67 \%$

$65 \%$

$70 \%$

$100 \%$

Days to Estrus

2.0

$11 / 16$

$5 / 6$

$83 \%$

$11 / 12$

$92 \%$

$10 / 18$

$56 \%$

$8 / 14$

$57 \%$

$9 / 13$

$69 \%$

$8 / 11$

$73 \%$

$5 / 7$

$71 \%$

2.5

$35 / 45$

$10 / 20$

$69 \%$

$78 \%$

3.0

Rank of Average Concentration of

Progesterone on Days 4 - 8

Upper fourth

$14 / 20$

$70 \%$

Middle half

$30 / 41$

$73 \%$

$12 / 20$

$60 \%$

Rank of Slope of Concentration of

Progesterone on Days 4 - 8

Upper fourth

$14 / 20$

$70 \%$

Middle half

$26 / 41$

$63 \%$

Lower fourth

$16 / 20$

$80 \%$

Side of Previous Corpus Luteum

Right

Left

Adjacent to Current Ovulation

Opposite to Current Ovulation
$42 / 56$

$15 / 25$

$30 / 44$

$27 / 37$
$75 \%$

$60 \%$

$68 \%$

$73 \%$ 


\section{Discussion}

Treatment with $\mathrm{PGF}_{2} \alpha$ on days 3, 3.5, and 4 produced the expected pattern of low, ascending progesterone early in the estrous cycle, but did not decrease fertility in cows that ovulated the first wave dominant follicle on day 12 or 13 after previous estrus. With the addition of this experiment, the effects of three different profiles of low progesterone on fertility have been investigated. These profiles will be discussed to illustrate how the results of the current research compare to data in the literature.

Shaham-Albalancy et al. (2000) gave injections of $\mathrm{PGF}_{2} \alpha$ to cows on $\mathrm{d} 3,3.5$, and 4 of the estrous cycle to cause a low ascending profile of progesterone. The resulting profile of plasma progesterone was lower than in cows with normal concentrations of progesterone (control), but higher than in cows given two injections of $\mathrm{PGF}_{2} \alpha$ on days 6 and 7, and two progesterone-releasing devices on day 6 (low constant progesterone). The authors proposed that the low ascending progesterone profile would mimic naturally occurring low concentrations of progesterone during the estrous cycle in cows, and that this model could be used to study the effects of this profile of progesterone on fertility. The first-wave dominant follicle was atretic on day 15 in cows with low ascending and normal concentrations of progesterone, but not in cows with low constant concentrations of progesterone. The atretic first-wave follicle in cows with low ascending concentrations of progesterone was larger than the atretic first-wave follicle in control cows $(15.0 \pm 1.4$ vs. $11.8 \pm 1.0 \mathrm{~mm})$. Although follicular fluid concentrations of estradiol in the first-wave atretic follicles were not different, the follicular fluid concentrations of estradiol in the largest healthy follicles (presumed second wave) were greater in cows with low ascending concentrations of progesterone than in the control cows. Growth of 
the first-wave atretic follicle and follicular fluid concentrations of estradiol in the largest healthy follicle were greater in cows with low ascending concentrations of progesterone than in control cows, indicating that LH pulse frequency probably was increased in cows with lower concentrations of progesterone.

Pregnancy rates (Savio et al., 1993b; Mihm et al., 1994; Smith and Stevenson, 1995; NE-161 Cooperative Research Project, 1996), oocyte viability (Revah and Butler, 1996), and embryonic survival (Ahmad et al., 1995) were decreased significantly in cows with extended periods of low progesterone. To achieve low progesterone in those studies, corpora lutea were regressed by injection of $\mathrm{PGF}_{2} \alpha$, and endogenous progesterone was replaced by progesterone-releasing devices. Mean concentrations of progesterone in these studies increased until the day of $\mathrm{PGF}_{2} \alpha$ injection, declined after injection of $\mathrm{PGF}_{2} \alpha$, and remained low until the progesterone-releasing device was removed.

It has been proposed that a period of 10 days of low progesterone is required to significantly decrease fertility (Mihm et al., 1994; Austin et al., 1999). Many studies have shown that events associated with a decrease in fertility occur after 9 days of low progesterone treatment (Ahmad et al., 1995; NE-161, 1996; Revah and Butler, 1996; Taft et al., 1996; Taft, 1999). Because the period of lowered progesterone in the present study was approximately 4 days, it may have occurred too early in the life of the follicle or may have been too short in duration to reduce fertility.

Premature oocyte maturation is the most likely mechanism for reduction of fertility in cattle with extended periods of low progesterone. Revah and Butler (1996) proposed that prolonged exposure to increased LH pulse frequency may stimulate oocyte 
maturation in cows. Mihm et al. (1999) proposed that a period of 10 days of dominance was required to initiate oocyte maturation in heifers. However, Taft (1999) observed changes in the oocyte associated with the resumption of meiosis after concentrations of progesterone were lowered for two days. Concentrations of progesterone in the study by Taft (1999) increased until day 6, when the injection of $\mathrm{PGF}_{2} \alpha$ was given. In the current study, progesterone secretion was reduced before it reached higher concentrations, but allowed to increase from days 4 to 9 . Initiation of meiosis and/or reduction of fertility may require high followed by low concentrations of progesterone.

Fertility was decreased in cows with lower concentrations of progesterone during the cycle before ovulation (Folman et al., 1973; Corah et al., 1974; Erb et al., 1976; Fonseca et al., 1983; Meisterling and Dailey, 1987). Concentrations of progesterone in milk of cows that conceived were $2 \mathrm{ng} / \mathrm{ml}$ or more greater than in cows that did not conceive (Meisterling and Dailey, 1987). In the current study, the average mean concentration of progesterone on days 4,6 , and 8 was lower $(\mathrm{p}<0.01)$ in treated $(3.1 \pm$ $0.2 \mathrm{ng} / \mathrm{ml})$ than in control $(3.8 \pm 0.2 \mathrm{ng} / \mathrm{ml})$ cows. This reduction may not have been great enough to significantly affect fertility. The period of low progesterone occurred throughout the estrous cycle in the studies cited above which fertility was decreased in cows with low ascending concentrations of progesterone. In the present study, the period of low progesterone occurred during only the first wave of follicular development. Again, the period of low progesterone in the present study may have been too short in duration to reduce fertility significantly.

In the current study, pregnancy rate was greater in cows that ovulated a follicle from the right versus left ovary. Fifty-eight percent of pregnancies occurred in the right 
uterine horn of 704 cows palpated for pregnancy (Clark, 1936). In their 1938 study on the functional activity of the right and left bovine ovary, Reece and Turner found that $73.5 \%$ of ovulations occurred on the right ovary of 136 mature heifers. They concluded that the right ovary was functionally more active and that this difference was responsible for increased pregnancy rate in the right uterine horn seen in other studies. Although an equal proportion of early postpartum cows ovulated from either ovary, pregnancy rate was increased in cows that ovulated a follicle from the right side (Bridges et al., 2000). In contrast, in dairy cows in which ovulation occurred more frequently on the right (62\%) versus left $(38 \%)$ ovary, pregnancy rate tended to be greater $(\mathrm{p}=0.079)$ when ovulation occurred on the left (79\%) versus right (63\%) ovary (David Townson et al., NE-161, unpublished data).

In conclusion, treatment with $\mathrm{PGF}_{2} \alpha$ on days 3 to 4 produced a pattern of low ascending concentrations of progesterone. However, this treatment did not decrease fertility in cows that ovulated the first wave dominant follicle. Although a low ascending profile of progesterone early in the estrous cycle did not affect fertility, several interesting findings were made. Pregnancy rate was greater in cows that ovulated a follicle from the right versus left ovary, and was greater in cows that came into estrus 2.5 compared to 2.0 or 3.0 days after injection of $\mathrm{PGF}_{2} \alpha$ on day 9 . 


\section{Literature Cited}

Adams GP, Matteri RL, Kastelic JP, Ko JCH, Ginther OJ. Association between surges of follicle-stimulating hormone and the emergence of follicular waves in heifers. $J$ Reprod Fert. 1992a; 94: 177-88.

Adams GP, Matteri RL, Ginther OJ. Effect of progesterone on ovarian follicles, emergence of follicular waves and circulating follicle-stimulating hormone in heifers. J Reprod Fertil. 1992b; 96: 627-40.

Ahmad N, Schrick N, Butcher RL, Inskeep EK. Effect of persistent follicles on early embryonic losses in beef cows. Biol Reprod. 1995; 52: 1129-35.

Austin EJ, Mihm M, Ryan MP, Williams DH, Roche JF. Effect of duration of dominance of the ovulatory follicle on onset of estrus and fertility in heifers. J Anim Sci. 1999; 77: 2219-26.

Beal WE, Milvae RA, Hansel W. Oestrus cycle length and plasma progesterone concentrations following administration of prostaglandin F-2a early in the bovine oestrous cycle. J Reprod Fertil. 1980; 59: 393-6.

Beck TW, Smith VG, Seguin BE, Convey EM. Bovine serum LH, GH and prolactin following chronic implantation of ovarian steroids and subsequent ovariectomy. $\mathrm{J}$ Anim Sci. 1976; 42: 461-8.

Beg MA, Bergfelt DA, Kot K, Wiltbank MC, Ginther OJ. Follicular-fluid factors and granulosa-cell gene expression associated with follicle deviation in cattle. Biol Reprod. 2001; 64: 432-41.

Bergfeld EG, Kojima FN, Cupp AS, Wehrman ME, Peters KE, Mariscal V, Sanchez T, Kinder JE. Changing dose of progesterone results in sudden changes in frequency of luteinizing hormone pulses and secretion of 17 beta-estradiol in bovine females. Biol Reprod. 1996;54: 546-53.

Bevers MM, Dieleman SJ, van den Hurk R, Ixadyar F. Regulation and modulation of oocyte maturation in the bovine. Theriogenology. 1997; 47: 13-22.

Bigelow KL, Fortune JE. Characteristics of prolonged dominant versus control follicles: follicle cell numbers, steroidogenic capabilities, and messenger ribonucleic acid for steroidogenic enzymes. Biol Reprod. 1998; 58: 1241-9.

Billig H, Furuta I, Hsueh AJW. Estrogens inhibit and androgens enhance ovarian granulosa cell apoptosis. Endocrinology. 1993; 133: 2204-12. 
Braden TD, King ME, Odde KG, Niswender GD. Development of preovulatory follicles expected to form short-lived corpora lutea in beef cows. J Reprod Fertil. 1989; 85: 97-104.

Breuel KF, Lewis PE, Schrick FN, Lishman AW, Inskeep EK, Butcher RL. Factors affecting fertility in the postpartum cow: role of the oocyte and follicle in conception rate. Biol Reprod. 1993; 48: 655-61.

Booth WD, Newcomb R, Strange H, Rowson LEA, Sacher HB. Plasma oestrogen and progesterone in relation to superovulation and egg recovery in the cow. Vet Rec. 1975; 97: 366-9.

Butcher RL, Pope RS. Role of estrogen during prolonged estrous cycles of the rat on subsequent embryonic death or development. Biol Reprod. 1979; 21: 491-5.

Clark CF. Does the right ovary of the bovine function more frequently than the left. J Am Vet Med Assn. 1936; 88: 62-5.

Corah LR, Quealy AP, Dunn TG, Kaltenbach CC. Prepartum and postpartum levels of progesterone and estradiol in beef heifers. J Anim Sci. 1974; 39: 380-5.

Cupp A, Garcia-Winder M, Zumudio A, Mariscal V, Wehrman M, Kojima N, Peters K, Bergfeld E, Hernandez P, Sanchez T, Kittock R, Kinder J. Two concentrations of progesterone (P4) in circulation have a different effect on pattern of ovarian follicular development in the cow. Biol Reprod. 1992; 45 (supplement 1): 106 (abstract 222).

Cupp A, Garcia-Winder M, Zumudio A, Mariscal V, Wherman M, Kojima N, Peters K, Bergfeld E, Hernandez P, Sanchez T, Kittock R, Kinder J. Concentration of progesterone (P4) in circulation has a differential effect on biochemical characteristics of dominant follicles in cows. J Anim Sci. 1993; 71 (supplement 1): 211 (abstract 484).

Dekel N, Beers WH. Rat oocyte maturation in vitro: relief of cyclic AMP inhibition by gonadotropins. Proc Natl Acad Sci USA. 1978; 75: 4369-73.

Dufour J, Cahill LP, Mauleon P. Short- and long-term effects of hypophysectomy and unilateral ovariectomy on ovarian follicular populations in sheep. J Reprod Fertil. 1979; 57: 301-9.

Eckery DC, Moeller CL, Nett TM, Sawyer HR. Recombinant bovine somatotropin (rbST, Sometribove) maintains the sensitivity of ovarian follicles to gonadotropins in hypophysectomized ewes. Biol Reprod. 1993; 48 (supplement 1): 142 (abstract 337). 
Erb RE, Garverick HA, Randel RD, Brown BL, Callahan CJ. Profiles of reproductive hormones associated with fertile and nonfertile inseminations of dairy cows. Theriogenology. 1976; 5: 227-42.

Fogwell RL, Weems CW, Lewis GS, Butcher RL, Inskeep EK. Secretion of steroids after induced luteal regression in beef heifers: Effects of $\mathrm{PGF}_{2} \bullet$ and removal of corpora lutea. J Anim Sci. 1978; 46: 1718-23.

Folman Y, Rosenberg M, Herz Z, Davidson M. The relationship between plasma progesterone concentrations and conception in post-partum dairy cows maintained on two levels of nutrition. J Reprod Fertil. 1973; 34: 267-78.

Fonseca FA, Britt JH, McDaniel BT, Wilk JC, Rakes AH. Reproductive traits of Holsteins and Jerseys: effects of age, milk yield and clinical abnormalities on involution of cervix and uterus, ovulation, estrous cycles, detection of estrus, conception rate and days open. J Dairy Sci. 1983; 66: 1128-47.

Fortune, JE. Ovarian follicular growth and development in mammals. Biol Reprod. 1994; 50(2): 225-32.

Gibbons JR, Wiltbank MC, Ginther OJ. Relationship between follicular development and the decline in the follicle-stimulating hormone surge in heifers. Biol Reprod. 1999; 60: 72-7.

Ginther OJ, Knopf L, Kastelic JP. Temporal associations among ovarian events in cattle during oestrous cycles with two and three follicular waves. J Reprod Fertil. 1989; 87: 223-30.

Ginther OJ, Wiltbank MC, Fricke PM, Gibbons JR, Kot K. Selection of the dominant follicle in cattle. Biol Reprod. 1996; 55: 1187-94.

Ginther OJ, Bergfelt DR, Kulick LJ, Kot K. Selection of the dominant follicle in cattle: role of two-way functional coupling between follicle stimulating hormone and the follicles. Biol Reprod. 2000a; 62: 920-7.

Ginther OJ, Bergfelt DR, Kulick LJ, Kot K. Selection of the dominant follicle in cattle: role of estradiol. Biol Reprod. 2000b; 63: 383-9.

Ginther OJ, Bergfelt DR, Beg MA, Kot K. Follicle selection in cattle: role of luteinizing hormone. Biol Reprod. 2001; 64: 197-205.

Glencross RG. Effect of pulsatile infusion of gonadotropin-releasing hormone on plasma oestradiol-17 $\beta$ concentrations and follicular development during naturally and artificially maintained high levels of plasma progesterone in heifers. J Endocrinol. 1987; 112: 77-85. 
Goodman RL, Karsch FJ. Pulsatile secretion of luteinizing hormone: differential suppression by ovarian steroids. Endocrinology. 1980; 107: 1286-90.

Granot I, Dekel N. Phosphorylation and expression of connexin-43 ovarian gap junction protein are regulated by luteinizing hormone. J Biol Chem. 1994; 269: 30502-9.

Granot I, Dekel N. Cell-to-cell communication in the ovarian follicle: development and hormonal regulation of the expression of connexin43. Hum Rprod. 1998; 13 Suppl 4: 85-97.

Greenwald GS and Roy SK. Follicular development and its control. The Physiology of Reproduction ( $2^{\text {nd }}$ edition). Knobil E and Neill JD. Raven Press Ltd. New York. 1994: 629-98.

Guthrie HD, Lamond DR, Henricks DM, Dickey JF. Ovarian follicular changes in heifers treated with melengestrol acetate. J Reprod Fertil. 1970; 22: 363-4.

Hill JR, Lamond DR, Henricks DM, Dickey JF, Niswender GD. The effect of melengesterol acetate (MGA) on ovarian function and fertilization in beef heifers. Biol Reprod. 1971; 4: 16-22.

Hobson WC, Hansel W. Plasma LH levels after ovariectomy, corpus lutum removal and estradiol administration in cattle. Endocrinology. 1972; 91: 185-90.

Hodgen GD. The dominant ovarian follicle. Fertil Steril. 1982; 38: 281-300.

Hughes RM, Gorospe WG. Biochemical identification of apoptosis (programmed cell death) in granulosa cells: evidence for a potential mechanism underlying follicular atresia. Endocrinology. 1991; 129: 2415-22.

Inskeep EK, Braden TD, Lewis PE, Garcia-Winder M, Niswender GD. Receptors for luteinizing hormone and follicle-stimulating hormone in largest follicles of postpartum beef cows. Biol Reprod. 1988; 38: 587-91.

Ireland JJ, Roche JF. Effect of progesterone on basal LH and episodic LH and FSH in heifers. J Reprod Fertil. 1982; 64: 295-302.

Ireland JJ, Mihm M, Austin E, Diskin MG, Roche JF. Historical perspective of turnover of dominant follicles during the bovine estrous cycle: key concepts, studies, advancements, and terms. J Dairy Sci. 2000; 83: 1648-58.

Karsch FJ, Cummins JT, Thomas GB, Clarke IJ. Steroid feedback inhibition of pulsatile secretion of gonadotropin-releasing hormone in the ewe. Biol Reprod. 1987; 36: 1207-18. 
Kesner JS, Convey EM, Anderson CR. Evidence that estradiol induces the preovulatory LH surge in cattle by increasing pituitary sensitivity to LHRH and then increasing LHRH release. Endocrinology. 1981; 108: 1386-91.

Kesner JS, Padmanabhan V, Convey EM. Estradiol induces and progesterone inhibits the preovulatory surges of luteinizing hormone and follicle-stimulating hormone in heifers. Biol Reprod. 1982; 26: 571-8.

Ko JCH, Kastelic JP, Del Campo MR, Ginther OJ. Effects of a dominant follicle on ovarian follicular dynamics during the oestrous cycle in heifers. J Reprod Fertil. 1991; 91: 511-9.

Kojima N, Stumpf TT, Cupp AS, Werth LA, Roberson MS, Wolfe MW, Kittock RJ, Kinder JE. Exogenous progesterone and progestins as used in estrous synchrony regimens do not mimic the corpus luteum in regulation of luteinizing hormone and 17- $\beta$ estradiol in circulation of cows. Biol Reprod. 1992; 47: 1009-17.

Kojima FN, Chenault JR, Wehrman ME, Bergfeld EG, Cupp AS, Werth LA, Mariscal V, Sanchez T, Kittock RJ, Kinder JE. Melengestrol acetate at greater doses than typically used for synchrony in bovine females does not mimic endogenous progesterone in regulation of secretion of luteinizing hormone and $17 \beta$-estradiol in circulation of cows. Biol Reprod. 1995; 52: 455-63.

Kulick LJ, Kot K, Wiltbank MC, Ginther OJ. Follicular and hormonal dynamics during the first follicular wave in heifers. Theriogenology. 1999; 52: 913-21.

Larson GH, Mallory DS, Dailey RA, Lewis PE. Gonadotropin concentrations, follicular development, and luteal function in pituitary stalk-transected ewes treated with bovine follicular fluid. J Anim Sci. 1991; 69: 4104-11.

Lewis PE, Bolt DJ, Inskeep EK. Pattern of luteinizing hormone release in progestin treated ewes. J Anim Sci. 1974, 38: 1204-9.

Manikkam M, Rajamahendran R. Progesterone-induced atresia of the proestrus dominant follicle in the bovine ovary: changes in diameter, insulin-like growth factor system, aromatase activity, steroid hormones, and apoptotic index. Biol Reprod. 1997; 57: 580-7.

Mattheij JA, Swarts JJ, van der Heijden AJ, van Helvoort AL, Kusters IC. Advancement of meiotic resumption in graafian follicles reduces fertility in the rat. Gynecol Obstet Invest. 1993; 36: 129-35.

McDonald MF, Bellve AR. Influence of oestrogen and progesterone on flow of fluid from the fallopian tube in the ovariectomized ewe. J Reprod Fertil. 1969; 20: 51- 
61.

Meisterling EM, Dailey RA. Use of concentrations of progesterone and estradiol-17 $\beta$ in milk in monitoring postpartum ovarian function in dairy cows. J Dairy Sci. 1990; 73: $1500-7$.

Menezo Y, Renard JP. The life of the egg before implantation. Reproduction in Mammals and Man. Thibault C, Levasseur MC, Hunter RHF. Ellipses. 1993; 349-67.

Mihm M, Baguisi A, Boland MP, Roche JF. Association between the duration of dominance of the ovulatory follicle and pregnancy rate in beef heifers. J Reprod Fertil. 1994; 102: 123-30.

Mihm M, Curran N, Hyttel P, Knight PG, Boland MP, Roche JF. Effect of dominant follicle persistence on follicular fluid oestradiol and inhibin and on oocyte maturation in heifers. J Reprod Fertil. 1999; 116: 293-304.

Momont HW, Seguin SE. $10^{\text {th }}$ International Congress on Animal Reproduction and Artificial Insemination, University of Illinois at Urbana-Champaign, Illinois, USDA, June 10-14, 1984. Volume 3: 336.1-336.3.

NE-161 Cooperative Regional Research Project. Relationship of fertility to patterns of ovarian follicular develoment and associated hormonal profiles in dairy cows and heifers. J Anim Sci. 1996; 74: 1943-52.

Pincus G, Enzmann EV. The comparitive behavior of mammalian eggs in vitro and in vivo. J Exp Med. 1935; 62: 655-75.

Rahe CH, Owens RE, Fleeger JL, Newton HJ, Harms PG. Pattern of plasma luteinizing hormone in the cyclic cow: dependance upon the period of the cycle.

Endocrinology. 1980; 107: 498-503.

Reece RP, Turner CW. The functional activity of the right and left bovine ovary. J Dairy Sci. 1938; 21: 37-9.

Revah I, Butler WR. Prolonged dominance of follicles and reduced viability of bovine oocytes. J Reprod Fertil. 1996; 106: 39-47.

Roberson MS, Wolfe MW, Stumpf TT, Kittock RJ, Kinder JE. Luteinizing hormone secretion and corpus luteum function in cows receiving two levels of progesterone. Bil Reprod. 1989; 41: 997-1003.

Sanchez T, Werhman ME, Bergfeld EG, Peters KE, Kojima FN, Cupp AS, Mariscal V, Kittock RJ, Rasby RJ, Kinder JE. Pregnancy rate is greater when the corpus 
luteum is present during the period of progestin treatment to synchronize time of estrus in cows and heifers. Biol Reprod. 1993; 49: 1102-7.

Sanchez T, Wehrman ME, Kojima FN, Cupp AS, Bergfeld EG, Peters KE, Mariscal V, Kittock RJ, Kinder JE. Dosage of the synthetic progestin, norgestomet, influences luteinizing hormone pulse frequency and endogenous secretion of $17 \mathrm{~b}$-estradiol in heifers. Biol Reprod. 1995; 52: 464-9.

Savio JD, Thatcher WW, Badinga L, de la Sota RL, Wolfenson D. Regulation of dominant follicle turnover during the estrous cycle in cows. J Reprod Fertil. 1993a; 97: 197-203.

Savio JD, Thatcher WW, Morris GR, Entwistle K, Drost M, Mattiacci MR. Effect of induction of low plasma progesterone concentrations with a progesteronereleasing intravaginal device on follicular turnover and fertility in cattle. J Reprod Fertil. 1993b; 98: 77-84.

Schallenberger E, Peterson AJ. Effect of ovariectomy on tonic gonadotropin secretion in cyclic and post-partum dairy cows. J Reprod Fertil. 1982; 64: 47-52.

Shaham-Albalancy A, Rosenberg M, Folman Y, Graber Y, Meidan R, Wolfenson D. Two methods of inducing low plasma progesterone concentrations have different effects on dominant follicles in cows. J Dairy Sci. 2000; 83: 2771-8.

Sheffel CE, Pratt BR, Ferrell WL, Inskeep EK. Induced corpora lutea in the beef cow. II. Effects of treatment with progestogen and gonadotropins. J Anim Sci. 1982; 54: 830-6.

Shelton K, Gayerie De Abreu MF, Hunter MG, Parkinson TJ, Lamming GE. Luteal inadequacy during the early luteal phase of subfertile cows. J Reprod Fertil. 1990; 90: 1-10.

Short RE, Howland BE, Randel RD, Christensen DS, Bellows RA. Induced LH release in spayed cows. J Anim Sci. 1973; 37: 551-7.

Sirois J, Fortune JE. Lengthening the bovine estrous cycle with low levels of exogenous progesterone: a model for studying ovarian follicular dominance. Endocrinology. 1990; 127: 916-25.

Smith MW, Stevenson JS. Fate of the dominant follicle, embryonic survival, and pregnancy rates in dairy cattle treated with prostaglandin $\mathrm{F}_{2} \alpha$ and progestins in the absence or presence of functional corpus luteum. J Anim Sci. 1995; 73: 3743-51.

Stock AE, Fortune JE. Ovarian follicular dominance in cattle: relationship between prolonged growth of the ovulatory follicle and endocrine parameters. 
Endocrinology. 1993; 132: 1108-14.

Taft R, Ahmad N, Inskeep EK. Exogenous pulses of luteinizing hormone cause persistence of the largest bovine ovarian follicle. J Anim Sci. 1996; 74: 2985-91.

Taft RA. Oocyte morphology and estrogen concnetrations following a reduction in progesterone in beef cattle. Dissertation. 1999; West Virginia University.

Telford NA, Watson AJ, Schultz GA. Transition from maternal to embryonic control in early mammalian development: a comparison of several species. Mol Reprod Dev. 1990; 26: 90-100.

Tilly JL, Kowalski KI, Johnson AL, Hsueh AJW. Involvement of apoptosis in ovarian follicular atresia and postovulatory regression. Endocrinology. 1991; 129: 2799801.

Townson DH, Tsang PCW, Butler WR, Frajblat M, Griel LC, Johnson CJ, Milvae RA, Niksic GM, Pate JL. Relationship of fertility yo ovarian follicular waves before breeding in dairy cows. NE-161, Cooperative Regional Research Project. Unpublished data.

Turzillo AM, Fortune JE. Effects of suppressing plasma FSH on ovarian follicular dominance in cattle. J Reprod Fertil. 1993; 98: 113-9.

Ulberg LC, Christian RE, Casida LE. Ovarian response to progesterone injections. J Anim Sci. 1951; 10: 752-9.

Wehrman ME, Roberson MS, Cupp AS, Kojima FN, Stumpf TT, Werth LA, Wolfe MW, Kittock RJ, Kinder JE. Increasing exogenous progesterone during synchronization of estrus decreases endogenous 17b-estradiol and increases conception in cows. Biol Reprod. 1993; 49: 214.

Wehrman ME, Fike KE, Melvin EJ, Kojima FN, Kinder JE. Development of a persistent ovarian follicle and associated elevated concentrations of 17b-estradiol preceding ovulation does not alter the pregnancy rate after embryo transfer in cattle. Theriogenology. 1997; 47: 1413-21.

Xu Z, Garverick HA, Smith GW, Smith MF, Hamilton SA, Youngquist RS. Expression of follicle-stimulating hormone and luteinizing hormone receptor messenger ribonucleic acids in bovine follicles during the first follicular wave. Biol Reprod. 1995; 53(4): 951-7.

Yang MY, Rajamahendran R. Morphological and biochemical identification of apoptosis in bovine follicular cells and effects of follicle stimulating hormone and insulinlike growth factor-I on spontaneous apoptosis in cultured bovine granulosal cells. Biol Reprod. 2000; 62: 1209-17. 
Zamboni L, Thompson RS, Smith DM. Fine morphology of human oocyte maturation in vitro. Biol Reprod. 1972; 7: 425-57.

Zimbelman RG, Smith LW. Control of ovulation in cattle with melengestrol acetate. II.effects on follicular size and activity. J Reprod Fertil. 1966; 11; 193-201. 


\section{Vita}

Jason Brian Candler

Birthplace St. Petersburg, FL

Date of Birth March 31, 1977

Schools Attended:

Westgate Elementary School..............................................................1982-1988

St. Petersburg, FL

Tyrone Middle School

1988-1991

St. Petersburg, FL

Dixie Hollins High School

Kenneth City, FL

University of Florida

Gainesville, FL

West Virginia University Morgantown, WV

Degrees Received:

Bachelor of Science in Animal Science

University of Florida, 1999

Master of Science in Reproductive Physiology

West Virginia University, 2001 